\title{
重度脳神経障害児の嚾下障害に対する外科的アプローチ：噴 門形成術後も持続する誤䓵性肺炎に対する喉頭気管分離手術
}

\author{
高見澤 滋, 津川 力, 西島 栄治, 連利博, \\ 佐藤志以樹, 伊勢 一哉, 前川 貴代
}

(兵庫県立こども病院外科)

要旨：脳神経障害児における䛊嚥性肺炎の原因として，胃食道逆流症とともに嚥下障害は大きな問 題であり, 逆流防止手術（噴門形成術）後も，残存する嚥下障害のために誤嚥性肺炎を繰り这す事 が少なくない。我々は, 噴門形成術後も誤嚥性肺炎を繰り返す重度脳神経障害児5例に対して, 喉頭 気管分離術：LTS（+気管食道吻合術）を行った。手術時年齢は2才2力月から16才3力月で, 噴門形 成術からLTSまでの期間は，2カ月～2年8カ月であった。本手術により，気管内吸引の回数は平均で 術前30分に1回から術後4.5時間に1回と著明に隇少し, 肺炎は 5 例中 4 例で完全に消失した。全例の 家族が手術を大変満足あるいはとても満足（5段階評価の 4 以上）していると回答している。本手術 は脳神経障害児の誤嚥を防止し，患児のQOLを著明に改善する有効な治療法である。

\section{Surgical approach to oropharyngeal dysphagia for neurologically impaired children:Laryngotracheal separation for aspiration pneumonia remaining after fundoplication}

\author{
Shigeru Takamizawa, Chikara Tsugawa, Eiji Nishijima, Toshihiro Muraji, \\ Shiiki Satoh, Kazuya Ise, Takayo Maekawa
}

\begin{abstract}
Aspiration pneumonia due to oropharyngeal dysphagia as well as gastroesophageal reflux (GER) is a vexing clinical problem in neurologically impaired children. Aspiration pneumonia may occur after successful fundoplication because of remaining difficulties of swallowing. We performed laryngotracheal separation (LTS) with/without end-to-side tracheoesophageal anastomosis as an anti-aspiration procedure for intractable aspiration pneumonia in five patients. All patients aged from 2.2 to 16.3 years had previously undergone fundoplication and gastrostomy. The neurological deficits causing aspiration include cerebral palsy after near drawing or hydrocephalus due to intracranial hemorrhage in 2 patients, Dandy-Walker syndrome in 1 , lissencephaly in 1 and Leigh's syndrome in 1 . None of these patients could speak. Only 2 patients could drink a small amount of liquid by mouth, although oral feeding was not achieved in the remaining 3 patients because of aspiration. Interval from fundoplication to LTS was ranged from 2 months to 2.7 years. LTS decreased frequency of suction from once every 30 minutes to once every 4.5 hours in average. Pneumonia was completely disappeared in 4 patients. All parents rated LTS excellent or good. LTS can prevent the neurologically impaired children from aspiration and provide higher quality of life.
\end{abstract}

Key words : 脳神経障害児，嚥下障害，誤嚥性肺炎，噴門形成術，喉頭気管分離術 


\section{【はじめに】}

重度の脳神経障害を有する患児において，誤 嚥性肺炎は患児の QOL を著しく低下させてい る。胃食道逆流症（GER）はその原因の一つで あり, 体位療法, 薬物療法等の保存的治療が無 効な場合，外科的治療（噴門形成術）が一般的 に行われている。しかし，噴門形成術により GERが防止された患児においても，脳神経障 害に起因する嚥下障害により，経口損取物の誤 嚥，あるいは経口搷取不可能な患児においても 唾液を誤嚥し, 肺炎を反復する事は少なくない。 唾液, 経口拱取物の䛊嚥は, 経管栄養あるいは 気管切開などにより予防されるが，その効果は 不確実である。我々は噴門形成術施行後も誤嚥 性肺炎を繰り返す脳神経障害児に対して, 唾液, 経口搷取物の気管内への流入を遮断し，誤嚥性 肺炎を防止する目的で，喉頭気管分離術を行い その成績を評価した。

\section{【対象・方法】}

\section{1. 対象}

2000 年 8 月から 2001 年 6 月の 11 カ月間に, 発語 を見ない重度の脳神経障害児で, 噴門形成術,

胃瘻造設術を施行後も, 誤嚥性肺炎を繰り返す 患児に対して，喉頭気管分離術（十気管食道吻 合術）を行った（表 1)。原疾患はDandy-Walker 症候群 1 例, 脳性麻瘻 2 例（溺水後, 脳内出血 後各 1 例), 滑脳症 1 例, Leigh 脳症 1 例であっ た。喉頭気管分離術のみをおこなった症例は2 例で, 手術時年齢は 9 才 3 力月, 6 才 2 力月で あった。また，喉頭気管分離術に気管食道吻合 術を加えた症例は 3 例で，手術時年齢は 16 才 3 力月， 2 才 2 力月， 5 才 1 力月，であった。手 術時体重は，8.7 24.2kgであった。喉頭気管
分離術施行時， 5 例全例にすでに胃食道逆流症 に対する噴門形成術，胃瘻造設術が施行されて いた。

2. 方法

<術前検査：Videofluoroscopy >

誤嚥を客観的に診断するために重要な検査 で，透視下に咽頭内へ少量の造影剂（非イオン 性造影剤：オムニパーク等）を注入し，透視画 像をビデオテープに撮影する。撮影したテープ をスロー再生することにより，嚥下運動，誤嚥 の有無を細部にわたり観察することが可能であ る。

\section{<手術 >}

Videofluoroscopyにより，誤嚥が明らかに なった症例を，臨床的な重症度もふまえて手術 適応としている。GER あるいは食道裂孔へル ニアを併発している症例に対しては, 噴門形成 術（十胃瘻造設術）も同時に行う。

頸部を横切開し，前頸筋群を正中で分け，甲 状腺を縦切開し，気管前面を露出する。反回神 経を損傷しないように注意し, 気管膜様部一食 道間を剥離し，気管を離断する。離断した下部 気管に術野抻管を行い，換気を保ちながら上部 気管の操作を行う。上部気管を食道前壁と端側 吻合する喉頭気管分離術＋気管食道吻合術で は, 気管を腹側から背頭側方向へ斜めに切断 (気 管腹側を第 3 気管軟骨, 気管膜様部は第 1 気管 軟骨尾側の高さに切開) し，上部気管が過度に 屈曲しないようにしている。上部気管の断端と, 縦切開した食道前壁とを吸収系を用い， 1 層連 続縫合を行う（図 1)。喉頭気管分離術のみの 場合は上部気管を縫合閉鎖する（図 2 )。下部 気管は皮唐と全周性に縫合し，気管皮虐瘦とし た。術後の肉芽形成を抑制し, 気管皮虐瘻開口

表 1 症 例

\begin{tabular}{|c|c|c|c|c|c|c|c|c|}
\hline 症例 & 原疾患 & 発語 & 術式 & 手術時年齡 & 性別 & 手術時体重 $(\mathrm{kg})$ & 噴門形成術 & 胃瘦 \\
\hline 1 & Dandy-Walker症候群 & - & 堠頭気管分離術 & $9 y 3 m$ & $M$ & 13.4 & + & + \\
\hline 2 & 溺水後脳性麻庫 & - & 喉頭気管分噰術 & $6 y 2 m$ & $M$ & 10.7 & + & + \\
\hline 3 & 䏚内出血後脳性麻椣 & - & 気管食道吻合術 & $16 y 3 m$ & $M$ & 24.2 & + & + \\
\hline 4 & 滑脳症 & - & 気管食道吻合術 & $2 y 2 m$ & $F$ & 8.7 & + & + \\
\hline 5 & Leigh脳症 & - & 気管食道吻合術 & $5 y 1 m$ & $M$ & 15.8 & + & + \\
\hline
\end{tabular}




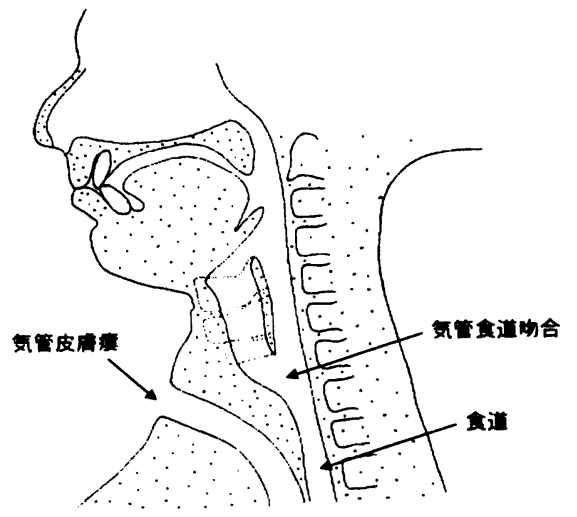

図 1 喉頭気管分離・気管食道吻合術

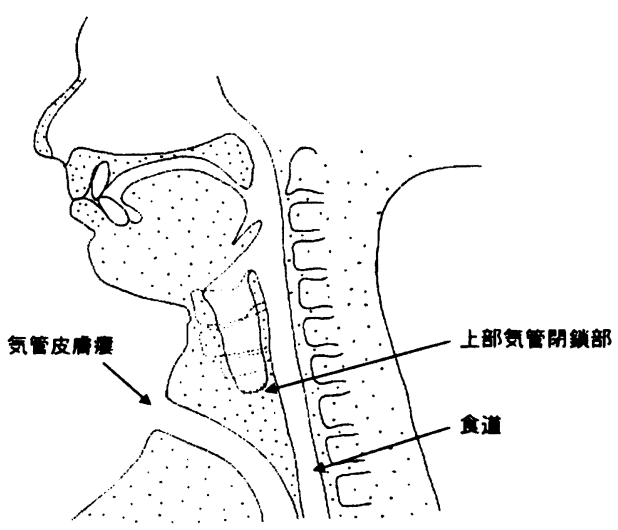

図 2 喉頭気管分離術
部の狭小化を防ぐために気管断端を皮虑で完全 に覆うことが肝要である。術後の気管内吸引を 容易とするため，また気管皮虚㾞開口部の狭小 化を防ぐ目的で，気管瘻へは気管切開チューブ を留置している。

\section{$<$ 評価 $>$}

術前後の状態（呼吸管理, 吸引の回数, 肺炎 の頻度), 術後合併症, 家族の手術に対する渵 足度を入院診療録あるいは家族へのアンケート 調査により評価した。

\section{【結果】}

噴門形成術後, 喉頭気管分離術（十気管食道 吻合術）が行われるまでの期間は， 2 力月〜 2 年 8 力月であった（表 2 ）。喉頭気管分離術前 の経口撕取は, 症例 3,5 において少量の水分 を経口可能であった以外は，症例 $1 ， 2 ， 4$ で は誤嚥を引き起こすため搷取は困難で, 全例と も胃瘦からの経管栄養がなされていた。術前気 管切開が施行されていた症例は 2 例であった が, 術前後とも, 人工呼吸器管理を必要とした 症例は無かった。術前15分〜120分毎に気管お よび口腔内吸引が必要であったが, 術後は 0.5 〜 8 時間に 1 回と軽度一著明に減少した（表 3 )。症例 3 において術後 1 回肺炎を起こした

表 2 結 果 1

\begin{tabular}{|c|c|c|c|c|}
\hline 症例 & 術式 & 嘪門形成術後期間 & 術前の経口椇取 & 術前気管切䦕の有無 \\
\hline \hline 1 & 喉頭気管分離術 & 2 y $8 \mathrm{~m}$ & - & - \\
\hline 2 & 喉頭気管分離術 & $2 \mathrm{~m}$ & - & - \\
\hline 3 & 気管食道吻合術 & $1 \mathrm{y} 3 \mathrm{~m}$ & 水分のみ可 & + \\
\hline 4 & 気管食道吻合術 & $6 \mathrm{~m}$ & - & - \\
\hline 5 & 気管食道吻合術 & $5 \mathrm{~m}$ & 少量の水分 & + \\
\hline
\end{tabular}

表 3 結 果 3

\begin{tabular}{|c|c|c|c|c|c|}
\hline 症例 & 術式 & 術前吸引類度 & 術後吸引回数(回/日) & 術後肺炎回数 & 合併症 \\
\hline 1 & 喉頭気管分離術 & 30 分毎 & $5 \sim 6$ 時間毎 & 0 & 気管皮膚度狭寉 \\
\hline 2 & 喉頭気管分離術 & $15 \sim 30$ 分毎 & $5 \sim 6$ 時間毎 & 0 & - \\
\hline 3 & 気管食道吻合術 & $15 \sim 30$ 分每 & 6〜8時間毎 & 1 & - \\
\hline 4 & 気管食道吻合術 & $30 \sim 120$ 分毎 & $3 \sim 4$ 時間毎 & 0 & - \\
\hline 5 & 気管食道吻合術 & $15 \sim 20$ 分毎 & $0.5 \sim 1$ 時間毎 & 0 & - \\
\hline
\end{tabular}


表 4 結 果 3

\begin{tabular}{|c|c|c|c|}
\hline 症例 & 赫式 & 満足度（理由） & 術後評価 \\
\hline 1 & 喉頭気管分倠術 & $4^{+} \sim 5$ & 吸引回数が堿り看謹が容易になった \\
\hline 2 & 堠頭気管分離衍 & $4^{+}$ & 吸引回数が減り看讙が容易になった \\
\hline 3 & 気管食道吻合術 & 5 & 吸引回数が減り看菨が容易になった \\
\hline 4 & 気管食道吻合術 & 4 & 看護の手間は增えたが、表情が良くなった \\
\hline 5 & 気管食道吻合術 & 4 & 経口摄取が可能になり、表情が良くなった \\
\hline
\end{tabular}

が，他の 4 例では術後肺炎は発症していない。 我々は基本的に，気管切開チューブを留置する 方針でいるが, 他院へ転院した症例 1 では, 気 管切開チューブを抜去し管理されていたため, 気管皮虐瘻開口部の狭窄を生じ, 気管皮唐瘦形 成術を行った。上部気管閉鎖部盲端，あるいは 気管食道吻合部の縫合不全, 感染等の合併症は 認められなかった。家族の手術に対する満足度 を 5 段階 $(5=$ 非常に満足, $4=$ 満足， $3=$ や や満足, 2 =やや不満, 1 =不満) でアンケー 卜調査したが， 5 例全例の家族が，患児の笑顔 が増し、QOLが著明に改善，また看護が容易 になり，非常に満足あるいは満足（5段階の 4 以上）していると回答した（表 4$)$ 。

\section{【考察】}

脳神経障害児において，原疾患に起因する嚥 下障害のため, 誤嚥性肺炎を繰り返す事が少な くない。抗生物質の長期的な投与, 時に入院治 療を要し, 原疾患の管理と共にその治療は大き な問題となっている。胃食道逆流症（GER）は 誤嚥性肺炎の原因として重要であり, 脳神経障 害を有する患児に併発することが多い。GER が疑われる患児に対しては, 上部消化管造影を 行い, GERの存在, 食道裂孔へルニア等の形 態異常を診断する必要がある。食道裂孔ヘルニ アの存在は噴門形成術の絶対的な適応である が，GERはその存在だけでは手術適応にはな らず, 逆流の程度が手術適応を決定することに なる。24時間 $\mathrm{pH}$ モニタリング検査は逆流の程 度を判定するのに有用であり, $\mathrm{pH}<4.00$ の 24 時 間時間率が $4 \%$ 越える場合を GER 陽性とする 1)。pH モニタリング検査において GER 陽性と 判定された症例でも, 逆流が軽度で, 体重増加 不良または誤嚥性肺炎などの呼吸器症状を認め
ない場合は体位療法，薬物療法（胃酸分泌抑制 剤： $\mathrm{H}_{2}$ ブロッカー, プロトンポンプインヒビ ター, 蠕動運動六進剂：ガスモチン）等の保存 的治療が行われるが, 保存的治療が無効な症例, あるいは初診時すでに体重増加不良, 呼吸器症 状等を認める症例に対しては外科的治療が考慮 され，噴門形成術が行われる。原疾患の重症度 ゆえ，経口摂取が将来的にも困難な患児に対し ては，より完全な逆流防止を行う目的で，下部 食道の全周 $\left(360^{\circ}\right)$ にわたりラッピングを行う Nissen 法が行われるが，当科では partial wrapping 法（3/4〜4/5周）を施行している。 逆流防止効果は, 下部食道のラッピングの程度 とともに, 手術によって形成される腹部食道の 長さにも強く影響されるため, 手術時に縦隔内 食道を剝離, 毫引儿, $3 \sim 5 \mathrm{~cm} \mathrm{~m}$ の十分な腹部 食道長を得るようにしている。術後経管栄養が 不可欠な患児に対しては同時にStamm 型の胃 瘻を造設している。近年腹腔鏡下に噴門形成術, および内視鏡的胃瘻造設術が施行されている が，当科では行っていない。

逆流防止手術施行後も誤嚥性肺炎を繰り返す 場合，経口掑取物，あるいは唾液そのものが喉 頭を通じ気管内へ流入する事が原因として考え られる。誤嚥を防止する目的で経管栄養を行い, 気管切開からの吸引により予防を行うが, 効果 は不十分な事が多く，誤嚥を防止する外科的な 治療が考慮される。誤嬹防止の外科的治療は, 解剖学的に気道と食道を分離することにより成 されるが，喉頭機能を犠牲にし，抜本的改善を 行う喉頭全摘術と, 喉頭機能を温存する喉頭気

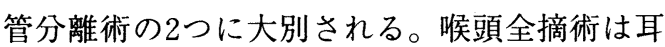
鼻咽喉科領域で一般的に行われている手術であ るが，発声機能が永続的に廃絶するため，家族 特に小児患児の家族には時に受け入れが困難な 
場合がある。一方喉頭機能を温存する喉頭気管 分離術は, 喉頭全摘術と同様, 発声機能は失わ れるが，気道の再建が可能であることが大きな 特徵である。1975年にLindeman らにより報告 された気管食道分流手術 (Diverting tracheoesophageal anastomosis) は, 離断され た上部気管を食道前壁に端側吻合し，下部気管 を気管皮虐瘻とする術式である2)。Lindeman らは翌1976年に, 高位気管切開のため, 上部気 管を食道と吻合することが不可能な症例に対し て，上部気管を縫合閉鎖する方法 (喉頭気管分 離術：Laryngotracheal separation）を報告した 3)。我々は喉頭へ流れ込む唾液, 食物をより生 理的に食道へ通過させることを考え，喉頭気管 分離術十気管食道吻合術（気管食道分流手術） を基本的に行い，高位気管切開のために，気管 食道吻合が不可能な症例に対しては喉頭気管分 離術を行っている。喉頭気管分離術において, 盲端となった喉頭に貯留する唾液は体位（背臥 位）によって, 声帯, 咽頭を経由し食道へ流れ 込むため，唾液の貯留による障害は生じず，両 術式間に効果, 成績の差はないと報告されてい $3^{4-6)}$ 。

本シリーズには含めていないが，誤嚥性肺炎 を繰り返し，経口摂取が困難であった交通外傷 後の脳性麻瘦患児 (12才) に対して喉頭気管分 離術を行ったが, 術後常食の経口摂取が可能と なった。この症例において，盲端となった喉頭 へ食物が貯留する事による問題は生じていな い。手術時すでに気管切開を有する年長児は, 気管切開が通常の位置にある場合においても, 気管軟骨が固く, 背側への屈曲が困難で, 食道 との吻合が出来ず，離断した上部気管を縫合閉 鎖せざるを得ない場合がある。

本手術の大きな特徴は, 気道の再建が可能な ことである ${ }^{3,7.8)}$ 。小児例においては，進行性 の脳神経障害を有する場合が多く, 嚥下機能が 改善する事は少なく, 気道の再建が行われる例 は稀であるが, 再建の可能性を残した本術式は, 手術を行う側, 受ける側の双方に受け入れられ やすい方法と言える。

当科では, 術後気管皮膚瘻へは気管切開 チューブを留置し管理するようにしている。年 少児では頸部が相対的に短く, 気管切開チュー
ブの装着がないと，自身で気管皮庴瘦を閉塞す る危険があり，また気管皮店瘦の絶対的な口径 が小さいため，自然に狭小化してしまう可能性 がある。また気管切開チューブ留置により，吸 引操作が容易となるため, 当科では基本的には 気管切開チューブを留置するように指導してい る。

本術式は気管内への誤嚥を完全に遮断するた め, 唾液, 経口摄取物の誤嚥による肺炎を起こ す可能性は皆無であるが, 原疾患の病状の進行 による胸郭運動障害, 喀痰の喀出困難などが原 因となり，肺炎を起こす事がある。我々の症例 でも， 5 例中 1 例に術後 1 回の肺炎を起こして いるが，今後原疾患の病状進行とともに肺炎を 起こす症例が増える事も予想される。しかし， 気管内吸引の回数は手術により著明に隇少した ため, 唾液の流入量が減少したことは明らかで あり，少なくとも誤嚥の原因を排除する事はで きると言える。4 5 時間に 1 回の吸引は家族 の看護を容易にし，患児の行動範囲が広がり， また肺炎治療のための入院を減らすことがで き，患児の QOL を著明に改善することができ る。

今日, 重度の脳神経障害児における反復性誤 嚥性肺炎の原因としての GER は, 噴門形成術, 胃瘻造設術により適切に治療されている。しか し喠液, 経口攝取物の䛊嚥に対しては, 経口搷 取の制限, 経管栄養, 気管切開による吸引処置 などが行われ，外科的な治療が積極的に行われ ていることは少ない。喉頭気管分離術（十気管 食道吻合術）は小览に対しても安全に施行可能 であり，また䛊嚥防止の効果は絶対であるだけ でなく，気道再建の可能性を残しているため, 家族にも受け入れられやすい方法である。GER を有する脳神経障害児の治療に際して，噴門形 成術, 胃㾞造設術に加之, 喉頭気管分離術 $(+$ 気管食道吻合術）も積極的に行っていくことが， 患児のQOLの更なる向上に槃がると考えられ る。

\section{【参考文献】}

1) 日本小児消化管機能研究会：24時間食道 $\mathrm{pH}$ モニタリングのガイドライン一検査法とその 
評価の標準化一，小児外科 $29 ： 1260-1263$, 1997.

2) Lindeman, R. C.: Diverting the paralyzed larynx: A reversible procedure for intractable aspiration. Laryngoscope $85:$ 157-180, 1975.

3 ) Lindeman, R. C., Yarington, Jr., C. T., Sutton D. : Clinical Experience with the tracheoesophageal anastomosis for intractable aspiration. Ann. Otol. 85 :609-612, 1976.

4 ) Snyderman, C. H., Johoson, J. T. Laryngotracheal separation for intractable aspiration. Ann. Otol. Rhinol. Laryngol. 97: 466-470, 1988.

5 ) Baron, B. C., Dedo, H. H. : Separation of the larynx and trachea for intractable aspiration. Laryngoscope. $90: 1927-1932,1980$.

6 ) 小河原 昇, 高松一郎, 陰里 ゆうみ, 他 : 若年者の難治性誤嚥に対する喉頭気管分 離・気管食道吻合術および喉頭気管分離術の 検討，日気食会報，47：463-468, 1996.

7 ) 北原 哲, 中之坊 学: Lindeman気管食道 吻合術のリリース手術の経験, 耳鼻, 45 : 540-542, 1999.

8 ) Eisele, D. W., Yarington, Jr., C. T., Lindeman, R. C. et al: The tracheoesophageal diversion and laryngotracheal separation procedures for treatment of intractable aspiration. Am J Surg. $157: 230-236,1989$. 